\title{
Why Stop There? Mexican Migration to the U.S. Border REgION
}

\author{
Pia M. Orrenius, Madeline Zavodny \\ AND LESLIE LUKENS
}

Research Department

Working Paper 0803 


\title{
Why Stop There? Mexican Migration to the U.S. Border Region"
}

Pia M. Orrenius, Ph.D.

Research Department

Federal Reserve Bank of Dallas and IZA

2200 N. Pearl St.

Dallas, TX 75201

(214) 922-5747

pia.orrenius@dal.frb.org
Madeline Zavodny, Ph.D.

Department of Economics

Agnes Scott College and IZA

141 E. College Ave.

Decatur, GA 30030

(404) 471-6377

mzavodny@agnesscott.edu

Leslie Lukens

LBJ School of Public Affairs

University of Texas at Austin

2315 Red River St.

Austin, TX 78712

(512) 469-7878

llukens@mail.utexas.edu

March, 2008

\begin{abstract}
The transformation of the U.S. border economy since the 1980s provides a fascinating backdrop to explore how migration to the U.S-side of the Mexican border has changed vis-à-vis migration to the U.S. interior. Some long-standing patterns of border migrants remained unchanged during this period while others underwent drastic changes. For example, border migrants are consistently more likely to be female, to have migrated within Mexico, and to lack migrant networks as compared with migrants to the U.S. interior. Meanwhile, the occupational profile of border migrants has changed drastically from being predominately agricultural work to being largely made up of service-sector and sales-related work. Border migration is more sensitive to Mexican and U.S. business cycles than migration to the U.S. interior throughout the period and, while the data suggest border migrant wages may have caught up to other migrants' wages by the early 2000s, multivariate analysis indicates that border migrants who are female and/or undocumented continue to earn far less than such migrants who work in the U.S. interior.
\end{abstract}

JEL Classification: J24, J31, J61

Key Words: migration, U.S.-Mexico border, wage gaps

\footnotetext{
"A version of this paper is a forthcoming chapter in Labor Market Issues along the U.S.-Mexico Border: Economic and Demographic Analyses (Marie Mora and Alberto Dávila, editors). The views expressed here are those of the authors and do not necessarily reflect those of the Federal Reserve Bank of Dallas or Federal Reserve System.
} 


\section{Why Stop There? Mexican Migration to the U.S. Border Region}

The U.S-Mexico border region has a unique economy and socio-demographic profile that sets it apart from the rest of the country. Perched between two giant nations, the border bears witness to over $\$ 350$ billion in cross-border trade and well over one hundred million border crossings every year, yet has remained one of the poorest regions in the U.S. At $\$ 30,904$, per capita income on the U.S. side of the border is 85 percent of the U.S. average. Without San Diego, border income is much lower-\$22,302-61 percent of the U.S. average. At the same time, the Mexican side of the border is one of the wealthiest regions in Mexico; income per capita in Mexican border states is about 1.5 times that of non-border states.

Despite the relatively small regional income gap along the border, Mexican migration to the U.S. side has increased over the past two decades, with most migrants coming from northern Mexico. As a result, the Mexican-born share of the U.S. population living along the border grew from about 10 percent in 1980 to over 15 percent in 2000, with most of that growth taking place in the 1990s. The obvious economic question is what factors drive Mexican migration into one of the poorest areas in the United States? In other words, why would Mexican migrants pass up more lucrative labor markets in the U.S. interior for a stint on the border?

Mexicans are the single largest group of immigrants in the U.S., numbering 11.1 million in 2005. The majority reside in just three states: California, Texas and Illinois. ${ }^{1}$ Most Mexican immigrants in the U.S. today entered the country without proper authorization at one time, although many have since legalized. ${ }^{2}$ Currently, about 56 percent of Mexican immigrants are undocumented (Passel, 2006), with many having paid several thousand dollars to be smuggled

\footnotetext{
${ }^{1}$ Overviews of Mexican immigration to the U.S. include Borjas (2007), Hanson (2006), and Massey et al (1987).

${ }^{2}$ We use the terms immigrant, migrant and foreign-born interchangeably throughout this article. Some researchers use 'immigrant' to refer exclusively to foreigners holding green cards or 'legal permanent residence'.
} 
across the Southwest border into the U.S. (Orrenius, 2001). ${ }^{3}$ This migration is largely driven by plentiful work opportunities in the U.S., although migrant networks and poor labor market conditions in Mexico play a large role in perpetuating Mexico-to-U.S. migration even during U.S. economic slowdowns. Mexican immigrants have relatively high labor force participation rates and low unemployment rates, but are among the least educated of all immigrant groups and tend to have low wages (Borjas and Katz, 2007). As a result, they have low assimilation rates as compared with other groups, although this also stems from their lack of English fluency, undocumented status, and traditional patterns of return migration (Lazear, 2007).

While we know quite a bit about Mexican migration to the U.S. in general, the literature typically examines migrants' experiences in traditional gateway destinations, such as Los Angeles, Chicago and Houston. Much less is known about Mexicans who choose to migrate to U.S. border cities. The research that has been done suggests border migrants are quite different from interior migrants. Dávila and Mora (2000) use Census data to compare the labor market characteristics of Mexicans across border and interior metropolitan areas and find that they differ in many respects, including English fluency, education, occupational distribution, and earnings.

There are many reasons why border migration should be distinct, including the uniqueness of the border economy, its two dominant languages and binational culture, large Hispanic labor force and geographic accessibility to Mexicans. The maquiladora industry is a powerful magnet that drives much of border migration on the Mexican side. On the U.S. side, geographic accessibility is key; for example, Mexicans with proof of employment and residence in Mexico have typically been able to apply for and receive a border crossing card from the U.S.

\footnotetext{
${ }^{3}$ Mexicans made up 86.1 percent of all entrants without authorization who were apprehended along U.S. borders in 2005 (Office of Immigration Statistics, 2006). Rounding out the top five origin countries were Honduras, El Salvador, Brazil and Guatemala.
} 
State Department which grants them permission to cross the border regularly and visit U.S. border cities.

This paper uses a unique data set, the Mexican Migration Project, to study how border migrants differ from average Mexican migrants with respect to their socio-demographic characteristics and migration patterns. We also consider whether migrants who work along the border earn significantly lower wages than those working in the U.S. interior and whether those wages represent a border wage penalty or something else. The results are consistent with a scenario in which access to fewer migrant networks and a strong geographic preference among border migrants may ultimately underlie their willingness to settle for lower wages on the border rather than seeking higher wages by venturing into the U.S. interior.

\section{The Border Economy: A Framework for Migration}

Given the prevalence of poverty and low education levels, the border region may in some ways appear more similar to Mexico than the rest of the U.S. Despite widespread poverty, however, the border is characterized by a dynamic economy and rapid employment growth. In the past, this has set the border region apart from other poor areas in the South where poverty is typically accompanied by economic stagnation and population decline (Dittmar and Phillips, 1999).

Since the mid-1980s, the border has been stimulated by massive changes in the Mexican economy, stemming in part from Mexico’s entry into GATT in 1986 and NAFTA in 1994,

ensuing economic diversification, and much improved monetary and fiscal policy (Orrenius and Berman, 2002). Peach and Adkisson (2007) discuss the impact that NAFTA in particular has had on the border economy, including faster job growth and falling unemployment rates. 
Growth in maquiladoras, large export-oriented manufacturing plants that line the Mexican side of the border, has also been instrumental in propelling border economic growth, although the manner in which maquiladoras do so has changed over time. Sargent et al. (2007) discuss how maquiladoras evolved in the post-NAFTA era, transitioning from high job growth in the late 1990s to relatively slow growth following the industry's contraction in 2000-2002. Despite the recent bust, maquiladoras in Mexican border states continue to employ close to one million workers and, while the majority of plants are located in and around Ciudad Juárez and Tijuana, the smaller border towns also have a significant maquiladora presence. In addition to its impact on border city economic growth, there is empirical evidence that by attracting workers to the border from other parts of Mexico, the maquiladora industry acts as an initial stage in the migration process that often leads to workers going to the U.S. (Kopinak, 2005; Rivera-Batiz, 1986).

The rapid job growth on the border since 1990, at 2.3 percent per year (compared to 1.4 percent for the U.S.), helped push border unemployment rates down from double to single digits, with unemployment reaching unprecedented lows in the early 2000s. Post-NAFTA, border job growth was marked by big expansions in transportation, government, financial and real estate, and retail and wholesale trade employment, with much of the growth tied to the rise in trade between Mexico and the U.S., border population growth, and the strength and stability of the Mexican peso. Since the late 1990s, the strong peso has motivated the dramatic influx of Mexican shoppers to U.S. border retail stores.

\footnotetext{
${ }^{4}$ Dávila and Sáenz (1990) find a negative short-run correlation between maquiladora employment growth and Border Patrol apprehensions. This is not inconsistent with a long-run relationship between growth in the maquiladora workforce and U.S. migration but suggests the timing of the impact may depend on relative economic conditions.
} 
More formal analysis of border business cycles in Texas supports the contention that, in the case of the smaller border cities, economic growth is predominantly driven by Mexican, not U.S., conditions (Phillips and Cañas, 2006). Larger U.S. border cities, such as El Paso, are more dependent on the maquiladora industry which is, in turn, dependent on the volume of U.S. industrial production and hence the U.S. business cycle.

Border economy characteristics help shape the region's labor demand and supply, which together hold important clues about what migrants to the region might look like. First of all, because of its location, the U.S. border likely attracts Mexican migrants who prefer to stay close to home, either because they have family in the northern Mexican states or because they are unwilling to take the risk of venturing into the relative unknown of the U.S. interior. It is also easier to cross legally or illegally into the border region than the U.S. interior since the latter requires that legally admitted foreigners fill out additional immigration forms (specifically, USCIS Form I-94) and that illegal entrants circumvent Border Patrol checkpoints along all major roads and highways. Lower migration costs also have implications for the self-selection of migrants and, all other things equal, should make selection among border migrants less positive as compared with migrants to the interior (Chiquiar and Hanson, 2005; Orrenius and Zavodny, 2005). Lower costs enable poorer and less-educated individuals to migrate.

Border migrants might prefer border cities over interior destinations because they don't have migrant networks in the U.S. interior, don't speak English or have little U.S. work experience. They may be skilled in occupations which are disproportionately common on the border, such as service and sales occupations, or in skilled occupations where native (U.S.-born) labor is scarce in the border region and hence wages are relatively high, such as professionalsarchitects, engineers, technicians, vocational teachers and college professors. Moreover, because 
of the border's high concentration of Border Patrol and other immigration and customs officials, the region likely attracts migrants who can cross the border legally, such as those who have temporary visas including tourist visas or border crossing cards. ${ }^{5}$

We are also interested to know what factors drive changes in migration to the border. Economic conditions in both the home and host region drive changes in migration over time, so wages and employment are likely key factors. ${ }^{6}$ Hanson and Spilimbergo (1999) find that Border Patrol apprehensions, a measure of illegal immigration, are sensitive to both Mexican and U.S. wages. A 10 percent decline in the real Mexican wage leads to a 7 to 9 percent increase in apprehensions, and the effect is very precisely estimated and conditional on the level of border enforcement. Using the MMP, Orrenius and Zavodny (2005) find that subcomponents of Mexican GDP and the real interest rate can better explain migration patterns than can Mexican manufacturing wages, although U.S. wages do positively and significantly impact migration northward. To the extent that it is easier to cross into the border than the U.S. interior, we expect border migration to be more sensitive to economic conditions than interior migration.

In addition to economic conditions, migrant networks have long been identified as key factors in Mexican migration decisions because they are a form of migration-related social capital. In fact, because a group's migration experience can have such a large impact on individuals, sociologists sometimes refer to the 'social process of migration' (Massey et al., 1987). In empirical work, networks are typically defined as relatives who have prior migration experience and who may even be living abroad. Networks are important to migration decisions

\footnotetext{
${ }^{5}$ Being able to cross the border legally does not mean that these migrants can work legally in the U.S., although many of them work anyway. It is also common to overstay these visas, at which point the migrant loses legal status.

${ }^{6}$ Wage inequality also changed in Mexico over the sample period, rising in the late 1980s and early 1990s and falling in the post-NAFTA period (Chiquiar, 2004; Robertson, 2007). This could also affect migration although we do not investigate those potential effects here.
} 
because they provide information to potential migrants about crossing the border and finding employment and housing in the U.S. In recent years, as illegal border crossings have become more dangerous and expensive, networks have also become an important means by which migrants raise funds to pay their smugglers. Because it is easier for Mexican newcomers both to get into U.S. border cities and to obtain housing and employment information, we expect networks should matter less to border migration than to interior migration. Although we could not find published work looking at this question for the border, Reyes and Mameesh (2002) found that Mexican migrants to Texas come from households with less migration history than migrants to interior destinations in Illinois and California.

\section{Data and Methods}

We use the Mexican Migration Project (MMP114) to investigate border migration and wages. $^{7}$ The MMP data, while it is not representative of all Mexican migrants to the U.S., is one of the few sources on the characteristics and time-varying migration behavior of undocumented and return migrants from Mexico. For a detailed discussion of the MMP surveys, see Durand and Massey (2004). Since 1982, the MMP has surveyed about 200 randomly selected households in each of 114 migration-prone Mexican communities, gathering basic migration and demographic information for all household members as well as complete retrospective migration histories of household heads. We focus on first and last U.S. trips made by males and females ages 12 and over who migrated to the U.S. for purposes of work between 1980 and 2005 and were not missing data on key variables, such as place of destination. Survey participants

\footnotetext{
${ }^{7}$ Office of Population Research, Princeton University. For information and data, go to http://mmp.opr.princeton.edu/
} 
reported on many dimensions of their migration, including where they were in the U.S. and for how long, their occupation and wage, and legal status. Household heads were also asked about their English fluency and family's migration experience. Fourteen percent of all individuals surveyed had at least one qualifying trip, for a sample of 17,144 trips.

The majority of MMP migrants are from western states, including Jalisco, Guanajuato, Michoacán, Colima and Aguascalientes — states in a region which has traditionally contributed large numbers of migrants to the U.S. (North and Houston, 1976). The other MMP states include Baja California Norte, Chihuahua, Nuevo León ('border' states); Sinaloa, Durango, Nayarit, Zacatecas, and San Luis Potosí ('northern'states); and Oaxaca, Puebla, Guerrero, Hidalgo, Tlaxcala, Veracruz and the state of México ('central' states). We define the following border cities as border destinations: San Diego, CA; Yuma, AZ; Tucson, AZ; Las Cruces, NM; El Paso, TX; Laredo, TX; McAllen, TX, and Brownsville, TX. ${ }^{8}$ During our sample period, 7.4 percent of trips were to the U.S. border and the remainder was to the U.S. interior. Top destinations for migrants to the interior U.S. were Los Angeles (26.7 percent), Chicago (10.7 percent), Houston (4.5 percent), Dallas (4.1 percent), Orange County (3.6 percent), and Fresno (3.1 percent). Migration to a border destination is modeled using a simple ordinary least squares (OLS) regression where migration is a function of migrant characteristics, economic conditions in Mexico and the U.S., U.S. immigration policy and time trends. Immigration policy variables include the number of temporary visas issued to Mexicans and the intensity of Border Patrol enforcement as measured by their hours spent patrolling the border ('linewatch' hours). The regression specification and the variables are described in more detail in the Appendix.

\footnotetext{
${ }^{8}$ Tucson and Las Cruces are not generally considered border cities since they are not located adjacent to Mexico. However, they are located in counties which are adjacent to the border and, given our small sample sizes, we chose to include them as border cities.
} 


\section{Summary Statistics: Characteristics of Border Migrants}

Mexican migrants to U.S. border cities differ significantly from Mexican migrants to other U.S. destinations during our sample period (see Table 1). They have more years of education, are more likely to be female and tend to come from slightly smaller families. They are less likely to report that they speak no English. These summary statistics (and those below) are consistent with Dávila and Mora (2000) who, using decadal Census data, also find that Mexicans on the border are more educated and have greater English fluency.

According to MMP, Mexican migrants on the border are much more likely to be from northern Mexico, with 53 percent from northern non-border states and 22 percent from border states, and from communities with less migration experience (hence fewer migrant networks). Migrants to the U.S. interior, meanwhile, tend to be from central and western Mexico and from communities with significantly more parent and sibling networks.

Border migrants are significantly less likely to cross into the U.S. illegally and are more likely to have a history as domestic migrants, migrating within Mexico before deciding to work in the U.S. Once in the U.S., border migrants are much more likely to hold service- and salessector jobs, while migrants to the U.S. interior are much more likely to be employed as production and farm workers. Overall, border migrants earn $\$ 1.61$ less per hour (in 2006 dollars) on average than migrants in the U.S. interior. There is a slightly higher concentration of professionals among border migrants as compared with migrants to the interior. An important subgroup among Mexican professionals on the border are factory owners, managers and 
executives, many of whom are likely working in maquiladoras in Mexico while living on the U.S. side of the border. ${ }^{9}$

There are interesting patterns over time. Between 1989 and 1997, the data show a rising share of trips to U.S. border cities vis-à-vis the U.S. interior (Figure 1). The spike in border migration in 1995 is particularly striking. Dubbed the 'Tequila Crisis', the 1995 Mexican economic downturn saw the value of the peso drop by 49 percent and Mexican GDP contract 7.1 percent. During this time, the border was an escape valve for Mexicans hurt by the recession. The drop-off in border migration after 1997 is largely an artifact of the way the MMP data is collected; the sample sizes become smaller towards the end of the time period as communities fall out of the sampling frame. The decline is particularly severe among border migrants since they are a much smaller sample to begin with.

In good times and bad, females are a disproportionate share of migrants to U.S. border cities (Figure 2). This likely stems from several factors, including the nature of border labor demand. Maquiladoras have traditionally relied on a predominately female workforce and have acted as a magnet for such migrants from other parts of Mexico. Also, female migrants have always found plentiful work opportunities along the U.S. side of the border in domestic service industries and, more recently, retail and hospitality. It may also be the case that female migrants prefer to remain close to their families, more so than male migrants, and so they are reluctant to venture into the U.S. interior. Sáenz et al. (2007) point out that Mexican immigrant women generally tend to cluster in jobs and areas that are predominately Mexican.

\footnotetext{
${ }^{9}$ The MMP data reports these as "U.S. occupations" although these workers are, in all likelihood, employed in Mexico.
} 
Over time, the share of trips that are illegal has been consistently lower among migrants to border cities than among migrants to the interior (Figure 3). The only exception to this pattern is the immediate aftermath of the 1986 amnesty (the Immigration Reform and Control Act), when the share of illegal immigration going to the interior hit a historic low. As the share of legal migrant workers going to border cities rose, their real wages also increased (Figure 4). According to the MMP data, average wages for border migrants reached the level of non-border migrants in 1999 at approximately $\$ 8.20$ per hour (in 2006 dollars). ${ }^{10}$

The transformation of the border economy discussed above is apparent in the next set of figures (Figures 5-7), which document the rise in the fraction of migrants involved in serviceand sales-related employment and the dramatic decline in the incidence of agricultural work. The percentage of migrants to the U.S. border who worked in agriculture declined from 60 percent in 1980 to less than 10 percent in 2004. During the same time period, the percentage of border migrants working in sales occupations nearly tripled to reach 33 percent of all migrants to border cities.

\section{Results}

\section{Migrant Choice of Destination}

Many of the differences between border and interior migration spells suggested by the figures are borne out by the regression results listed in Table 2. Border migrants are much more likely to be female and to first have migrated domestically. They have significantly fewer migrant networks and are less likely to be on their first trip than are migrants to the U.S. interior.

\footnotetext{
${ }^{10}$ Dávila and Mora (2007) also find that the earnings of Mexican immigrants along the border improved relative to Mexicans in the interior between 1990 and 2000, although they do not find that the difference goes to zero. Note again that the tails of the MMP data are less reliable because the sample shrinks as communities fall out.
} 
The picture that emerges is one where border migrants come from communities with a shorter migration history and less U.S. migration overall than do migrants to the U.S. interior. As a result, they are less vested in U.S. migration and are likely to also try domestic (within Mexico) migration. Because their time is more divided between the U.S. and Mexico, they have slightly fewer U.S. trips and less U.S. experience than do migrants to the interior (as shown in Table 1). In essence, border migration appears to be slightly less structural in nature and perhaps more circular and less permanent. However, average U.S. trip durations are not shorter among border migrants than they are among migrants to the interior, which is a bit puzzling.

These differences hold up across the various specifications in Table 2 as we add more control variables for region of origin (column 2), economic conditions (column 3) and U.S. immigration policy (column 4). The results from column 2 confirm that border migrants are much more likely to be from Mexican border states and from northern Mexican states than are migrants to the U.S. interior. Adding region-of-origin control variables renders the coefficient on illegal status insignificantly different from zero, which suggests that migrants to the border are less likely to make illegal crossings but that this is largely a result of their northern Mexican origins. Residents of northern Mexico are more apt to have border crossing cards or other temporary visas than are Mexicans in the center and south of the country, hence they are more likely to cross the border legally (this does not mean that they have legal permission to work, which typically requires a work-based visa, a green card or U.S. citizenship).

Economic conditions also influence border migration in much the same way as we predicted with the exception of border employment, which takes on the wrong sign (Table 2, columns 3 and 4). Clearly, one would expect border employment growth to attract, not repel, migrant workers. In our preferred specification in column 4, labor demand appears to be better 
captured by U.S. employment as a whole; that coefficient is strongly positive and suggests that a 10 percent increase in employment leads to a 15 percent increase in migration to border cities. It is possible that our measure of border employment has the wrong sign because it is picking up the effect of Mexican employment growth. We discussed above how the border economy is strongly influenced by Mexican conditions, more so than by the U.S. economy, which suggests that border employment is highly correlated with employment on the Mexican side. In other words, our measure of border employment confounds Mexican economic conditions, which tend to push out Mexicans when bad, and U.S. economic conditions, which tend to pull in Mexicans when good.

In general, the results suggest that border migration is much more sensitive to U.S. and Mexican economic conditions than migration to the interior. In addition to the large coefficient on U.S. employment, there is also a very large significant effect of Mexican GDP and interest rates on border migration. According to the results, a 1 percent decline in Mexican GDP leads to a 0.4 percent rise in border migration. A 10 percent rise in short-term interest rates leads similarly to a 0.4 percent rise in border migration relative to migration to the interior.

Column 4 also adds the immigration policy variables, and the results are also as one would predict. Visa issuances are correlated with worker migration to the border, significantly more so than they are correlated with such migration to the interior. This is despite the fact that these visas are overwhelmingly for tourists, not workers, and those who work in the U.S. while on tourist visas are violating the law. While visas attract border migration, Border Patrol enforcement repels it. The coefficient on linewatch hours is large and negative, suggesting that a 10 percent increase in linewatch hours reduces border migration relative to interior migration by 2.7 percent. This result is consistent with the studies that have documented a pronounced 
increase in border relative to interior enforcement during the sample period, particularly in the years following the passage of IRCA (Dávila, Pagán and Grau, 1999).

\section{Migrant Wages}

As we saw above, border migrants are distinct in many ways, but it is unclear how these differences will play out in terms of the rewards to migration - their wages. From Table 1, we know that border migrants earn significantly less than migrants to the U.S. interior. What factors underlie this earnings differential? We estimated simple wage regressions of real hourly wages (in natural logs) of all U.S. migrants with many of the same covariates as in Table 2, although we exclude the aggregate variables such as economic conditions and immigration policy. These regressions include less than half of the original observations because there are so many missing values for wages, presumably because the survey respondents do not always know what their family members' wages were in the U.S. (in the cases where the migrant himself is not present to answer the survey). The regression results are listed in Table 3, with column 2 adding control variables for region of origin and column 3 adding interactions of certain key variables with a border dummy variable.

Migrant wages are substantially lower for border workers, older workers, females and workers with illegal status. They are significantly higher for workers with more years of education (although an additional year of education is only associated with a 1 percent rise in wages). Despite the fact that education is relatively scarce on the border, the interaction term of education and border is not statistically significant, suggesting that returns to education are not higher on the border after all—at least not for Mexican migrants. This result could have 
something to do with the limited transferability of education credentials or the low quality of Mexican schooling in origin communities.

Females earn 25 to 27 percent less than otherwise-similar men, a gap that is substantially larger for females who work on the border. The coefficient on the interaction between female and border in column 3 suggests an additional 16 percent deficit for women who stay close to Mexico. Sáenz et al. (2007) find a smaller border wage penalty for Mexican women, about 8.3 percent, but they limit their analysis to the four border states. Some of the earnings differential is due to the type of jobs Mexican immigrant women tend to hold, particularly on the border, such as nannies, housekeepers and retail workers. Dávila and Mora (2000) note that occupational sorting of Mexican females on the border into the low-paying service sector has suppressed their earnings.

Illegal immigrants earn about 14 percent less than otherwise-similar workers who crossed the border legally. This gap is even larger along the border, as indicated by the large negative coefficient on the interaction of illegal and border in column 3 (-0.16). U.S. work experience is also an important determinant of wages, although the coefficient on the border interaction suggests that U.S. experience is less valued on the border than in the interior (it is not statistically significant, however).

Is there a border wage penalty? The coefficient on the border destination dummy in columns 1 and 2 is significant and negative and suggestive of a border wage penalty of 16 to 20 percent. However, once the border interactions are included in column 3, the border wage penalty appears to be largely related to the nature of the border labor supply and border skill prices. Border migrants earn less on average because they are more likely to be female than migrants to the interior. Also, illegal immigrants on the border earn significantly less, 
presumably because they have to compete with a large binational pool of workers full of people with similar skills and backgrounds but who can work legally in the U.S.

\section{Conclusions and Policy Implications}

This study uses unique Mexican household survey data to look at how border migration differs from Mexican migration to the U.S. interior. Border migrants are more likely to be female, to have migrated within Mexico and to lack migrant networks as compared with migrants to the U.S. interior. Over time, the occupational profile of border migrants has changed from being predominately agricultural work to being largely made up of service-sector and salesrelated work. Border migration has also become predominately legal.

Border migration has remained highly sensitive to Mexican and U.S. business cycles and to immigration policy variables, much more so than migration to the U.S. interior. And while the data suggest raw border migrant wages caught up to other migrants' wages by the early 2000s, wage regressions indicate that border migrants who are female and/or undocumented continue to earn far less than such migrants who choose to work in the U.S. interior. It is likely that access to fewer migrant networks and strong geographic preferences, driven by a desire for proximity to Mexico, outweigh the wage penalty in the minds of these migrants and help account for their concentration along the border. The cost of living is also lower along the border, which further shrinks the 'real' wage gap with the interior.

An interesting extension of these findings is to ask whether the border migration pattern discussed here is along the lines of what one would expect if a guest-worker program were implemented to allow for the legal temporary migration of Mexican workers to the U.S. Similar to border migration, guest-worker migration would be highly cyclical, largely temporary and 
attractive to Mexican workers who desire short-term employment in the U.S. Conditional on having an employment offer, guest workers would face much lower migration costs than illegal immigrants to the interior, much like many border migrants today. The result would be flexible migration and less public burden associated with permanent settlement, but also more female migrants and migrants with less education. 


\section{References}

Banco de Mexico. http://www.banxico.org.mx.

Bean, Frank D., Barry Edmonston and Jeffrey S. Passel, eds. 1990. Undocumented migration to the United States: IRCA and the experience of the 1980s. Lanham, MD: University Press of America.

Borjas, George, ed. 2007. Mexican immigration to the United States. Chicago: University of Chicago Press.

Borjas, George J. and Lawrence F. Katz. 2007. Evolution of the Mexican-born workforce in the United States. In Mexican immigration to the United States, ed. George J. Borjas, 13-55.

Chicago: University of Chicago Press.

Chiquiar, Daniel. 2004. Globalization, regional wage differentials, and the Stolper-Samuelson theorem: Evidence from Mexico. Banco de México Working Paper \#2004-06.

Chiquiar, Daniel and Gordon H. Hanson. 2005. International migration, self-selection, and the distribution of wages: Evidence from Mexico and the United States. Journal of Political Economy 113: 239-81.

Dávila, Alberto, José A. Pagán and Montserrat Viladrich Grau. 1999. Immigration reform, the INS, and the distribution of interior and border enforcement resources. Public Choice 99: 32745 .

Dávila, Alberto and Marie T. Mora. 2000. English skills, earnings, and the occupational sorting of Mexican Americans along the U.S.-Mexico border. International Migration Review 34: 13357.

Dávila, Alberto and Marie T. Mora. 2007. Changes in the relative earnings gap between natives and immigrants along the U.S.-Mexico Border. Journal of Regional Science (forthcoming).

Dávila, Alberto and Rogelio Sáenz. 1990. The effect of maquiladora employment on the monthly flow of Mexican undocumented immigration to the U.S., 1978-1982. International Migration Review 24: 96-107.

Dittmar, Eric and Keith Phillips. 1999. Border region makes progress in the 1990s. Federal Reserve Bank of Dallas Vista.

Durand, Jorge, and Douglas S. Massey. 2004. What we learned from the Mexican Migration Project. In Crossing the border: Research from the Mexican Migration Project, ed. Jorge Durand and Douglas S. Massey, 1-14. New York: Russell Sage Foundation.

Instituto Nacional de Estadística Geografía e Informática. http://www.inegi.gob.mx/inegi. 
Hanson, Gordon H. 2006. Illegal migration from Mexico to the United States. Journal of Economic Literature 44: 869-924.

Hanson, Gordon H. and Antonio Spilimbergo. 1999. Illegal immigration, border enforcement, and relative wages: Evidence from apprehensions at the U.S.-Mexico Border. American Economic Review 89: 1337-57.

Kopinak, Kathryn. 2005. The relationship between employment in maquiladora industries in Mexico and labor migration to the United States. The Center for Comparative Immigration Studies Working Paper 120.

Lazear, Edward P. 2007. Mexican assimilation in the United States. In Mexican immigration to the United States, ed. George J. Borjas, 107-22. Chicago: University of Chicago Press.

Massey, Douglas S., Rafael Alarcón, Jorge Durand, and Humberto Gonzalez. 1987. Return to Aztlan: The social process of international migration from Western Mexico. Berkeley: University of California Press.

North, David S. and Marion F. Houstoun. 1976. The characteristics and role of illegal aliens in the US labor market, an exploratory study. Washington, DC: Linton.

Orrenius, Pia M. 2001. Illegal immigration and enforcement along the U.S.-Mexico border: An overview. Federal Reserve Bank of Dallas Economic and Financial Review 1: 1-11.

Orrenius, Pia M. and Anna Berman. 2002. Growth on the border or bordering on growth? Federal Reserve Bank of Dallas SouthwestEconomy 3: 1-8.

Orrenius, Pia M. and Madeline Zavodny. 2005. Self-selection among undocumented immigrants from Mexico. Journal of Development Economics 78: 215-40.

Passel, Jeffrey S. 2006. The size and characteristics of the unauthorized migrant population in the U.S. Washington, D.C.: Pew Hispanic Center. http://pewhispanic.org/files/reports/61.pdf

Peach, James T. and Richard V. Adkisson. 2007. NAFTA and economic activity along the U.S.Mexico Border. In Labor market issues along the U.S.-Mexico border: Demographic and economic analyses, ed. Marie T. Mora and Alberto Dávila, unpublished manuscript (under contingent contract, University of Arizona Press).

Phillips, Keith and Jesús Cañas. 2006. Texas border business cycle indexes. In Basic border econometrics, ed. Martha Patricia Barraza de Anda and Thomas M. Fullerton, Jr., 196-214. Ciudad Juárez, Mexico: Procesos Gráficos S.A. de C.V.

Reyes, Belinda I. and Laura Mameesh. 2002. Why does immigrant trip duration vary across U.S. destinations? Social Science Quarterly 83: 580-93. 
Rivera-Batiz, Francisco L. 1986. Can border industries be a substitute for immigration? American Economic Review 76: 263-68.

Robertson, Raymond. 2007. Globalization and Mexican labor markets. In Migration, trade and development proceedings, ed. James F. Hollifield, Pia M. Orrenius and Thomas Osang (forthcoming). Dallas: Federal Reserve Bank of Dallas.

Sáenz, Rogelio, Lorena Murga and María Cristina Morales. 2007. Wage determinants of Mexican immigrant women along the Mexican-U.S. border. In Labor market issues along the U.S.-Mexico border: Demographic and economic analyses, ed. Marie T. Mora and Alberto Dávila, unpublished manuscript (under contingent contract, University of Arizona Press).

Sargent, John, Melissa Najera, and Linda Matthews. 2007. Labor market dynamics and a look inside border maquiladoras. In Labor market issues along the U.S.-Mexico border: Demographic and economic analyses, ed. Marie T. Mora and Alberto Dávila, unpublished manuscript (under contingent contract, University of Arizona Press).

U.S. Bureau of Economic Analysis. 1980-2004. Regional economicaccounts. http://www.bea.gov.

U.S. Bureau of Economic Analysis. 1980-2004. National economic accounts. http://www.bea.gov.

U.S. Bureau of Labor Statistics. 1980-2004. Current employment statistics. http://www.bls.gov.

U.S. Department of Homeland Security Office of Immigration Statistics. 2006. Fact Sheet: Border Apprehensions 2005. http://www.dhs.gov/immigrationstatistics

U.S. Department of the State, Bureau of the Consular. http://travel.state.gov 
Figures 1, 2

Percent of Migrant Workers going to Border Cities

Three-Year Moving Average

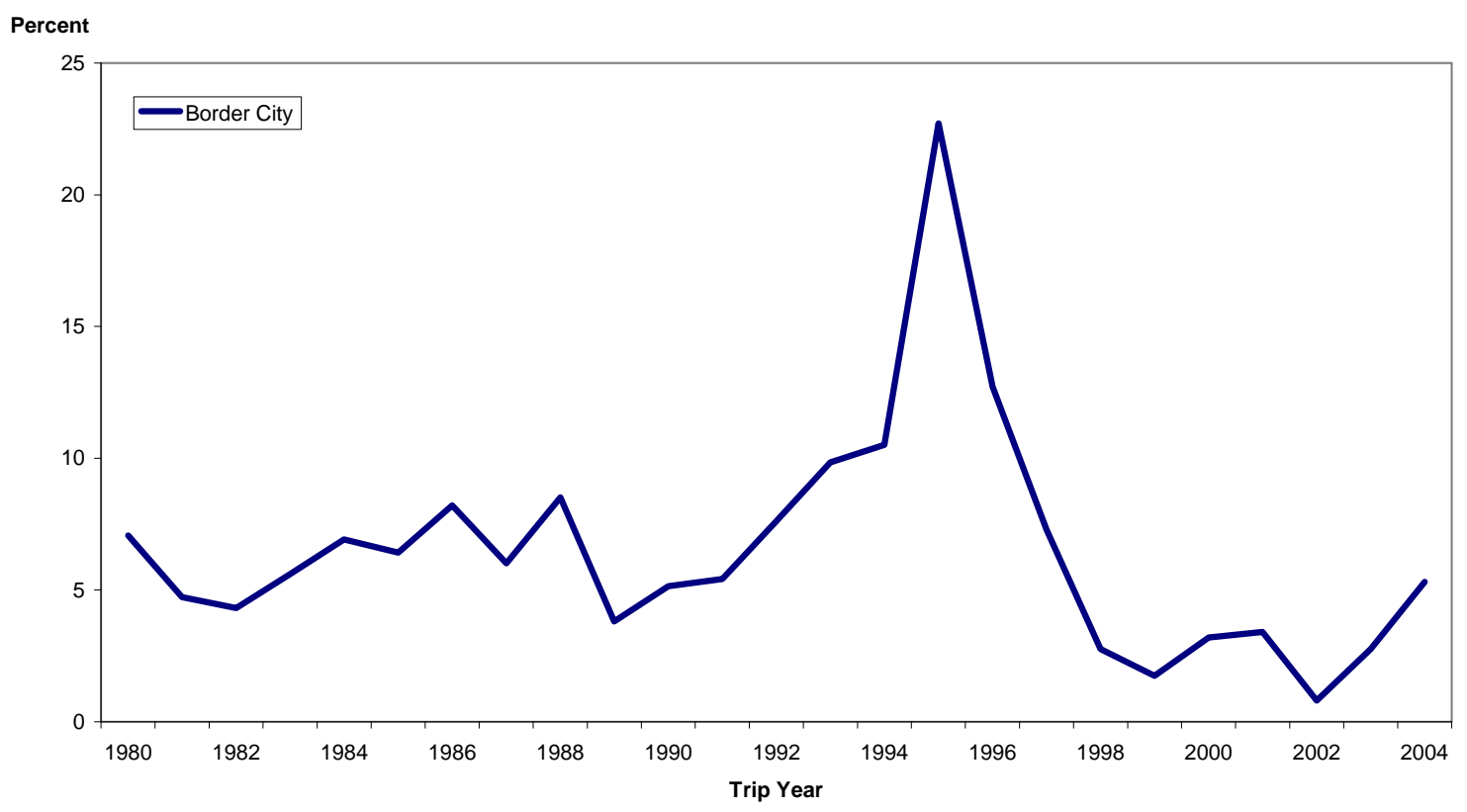

Source: Mexican Migration Project 114

Percent of Migrant Workers that are Female Three-Year Moving Average

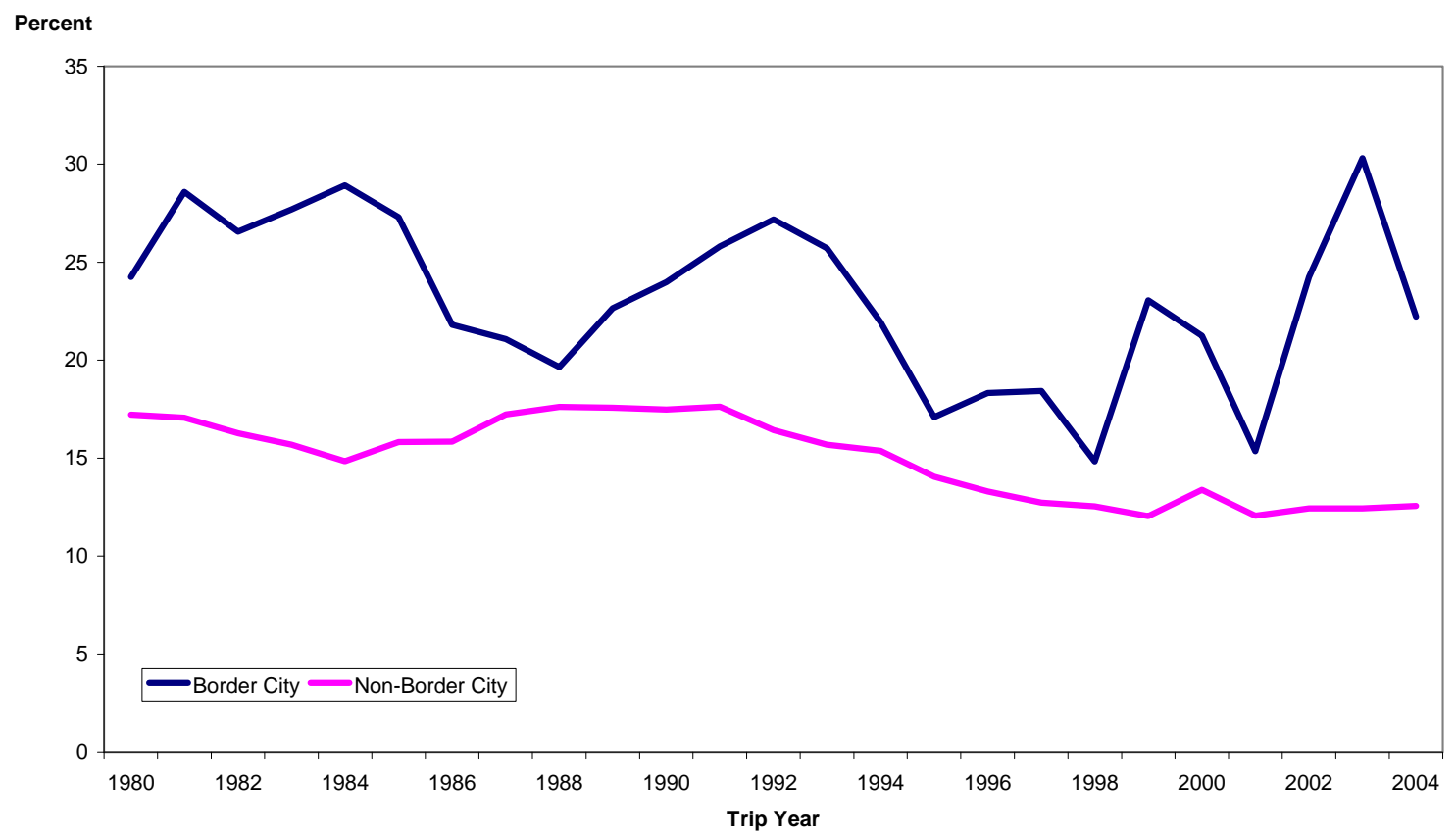

Source: Mexican Migration Project 114 
Figures 3, 4

Percent of Migrant Workers Illegally Entering the US

Three-Year Moving Average

Percent

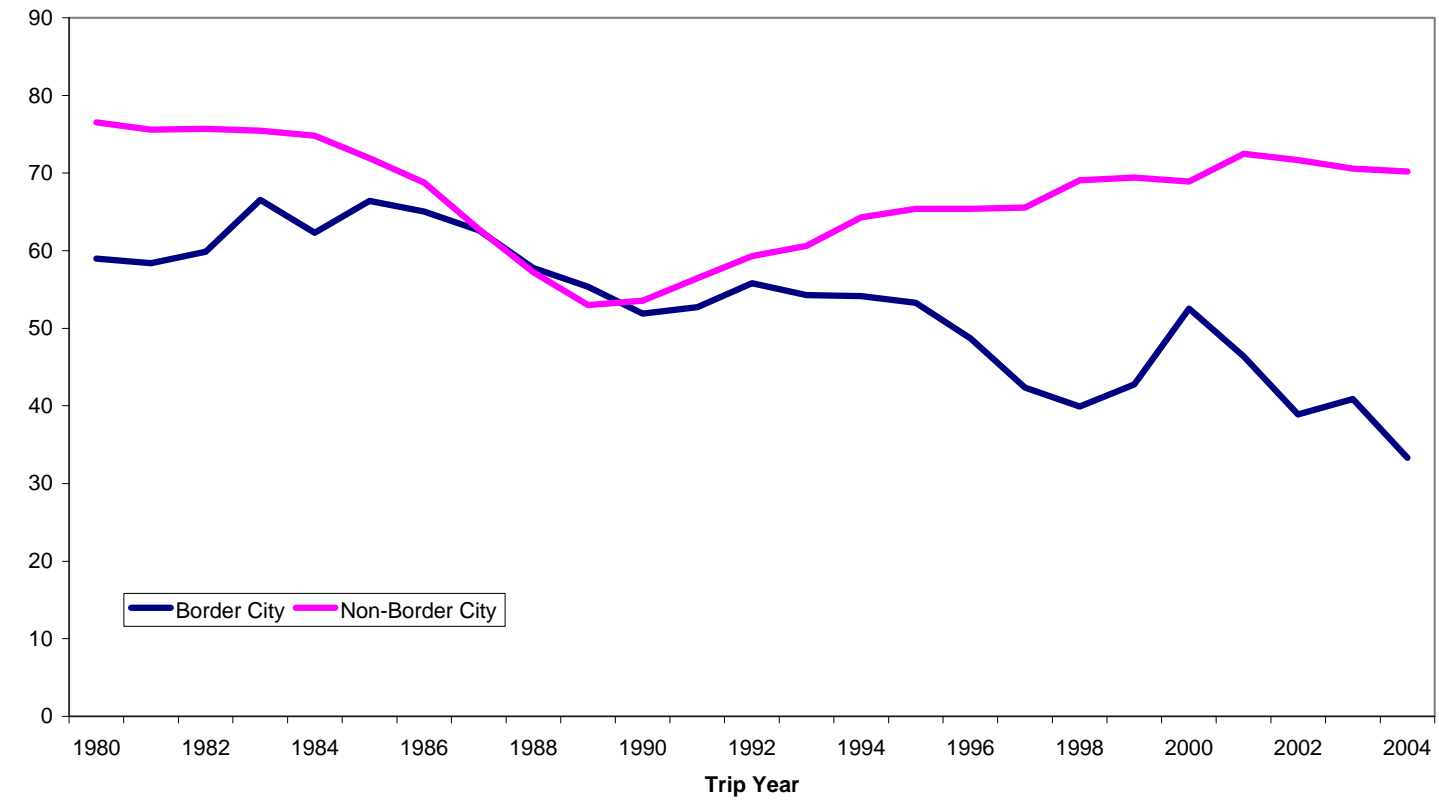

Source: Mexican Migration Project 114

Average Migrant Worker Wage

Three-Year Moving Average

US dollars per hour

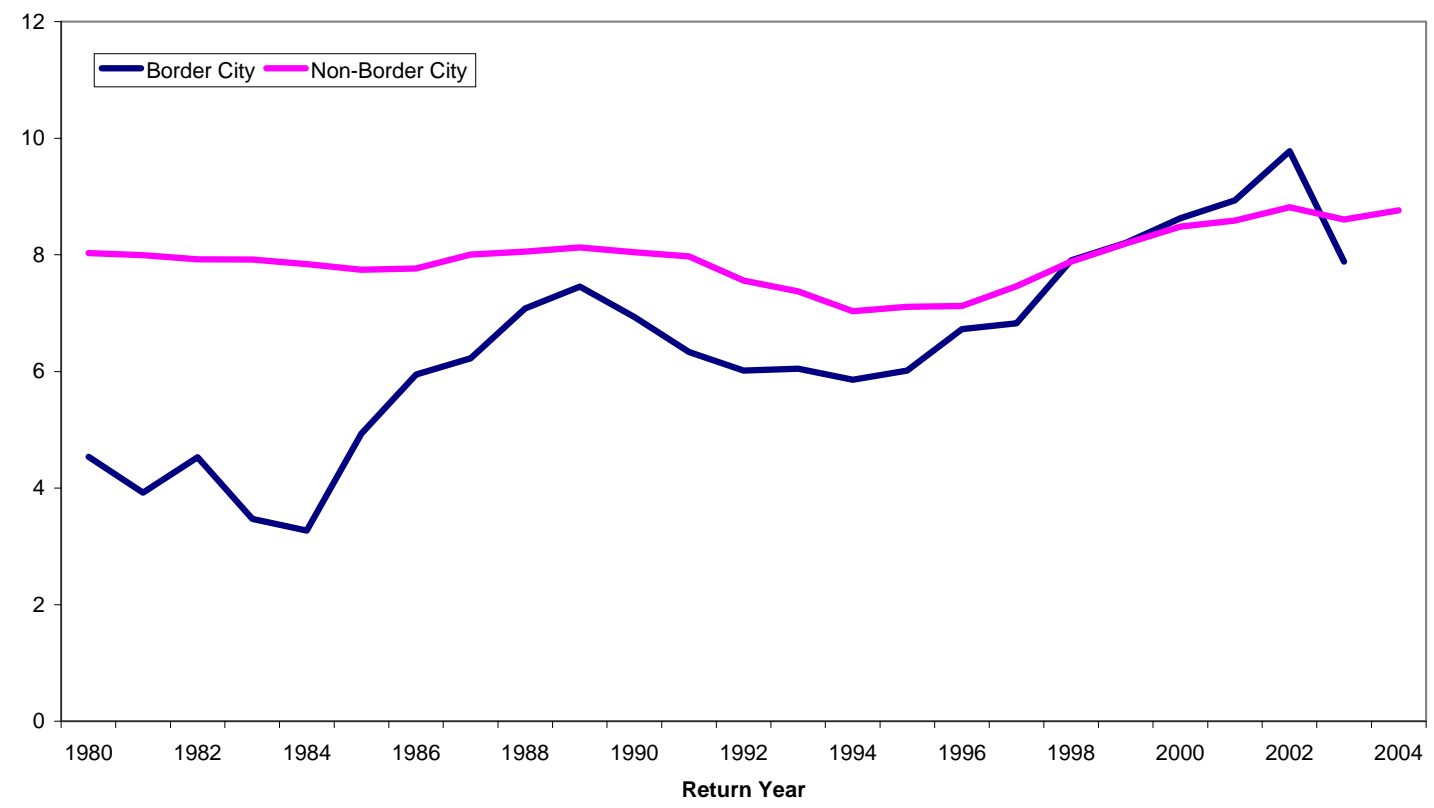

Source: Mexican Migration Project 114 
Figures 5, 6

Percent of Migrant Workers in Service Occupations

Three-Year Moving Average

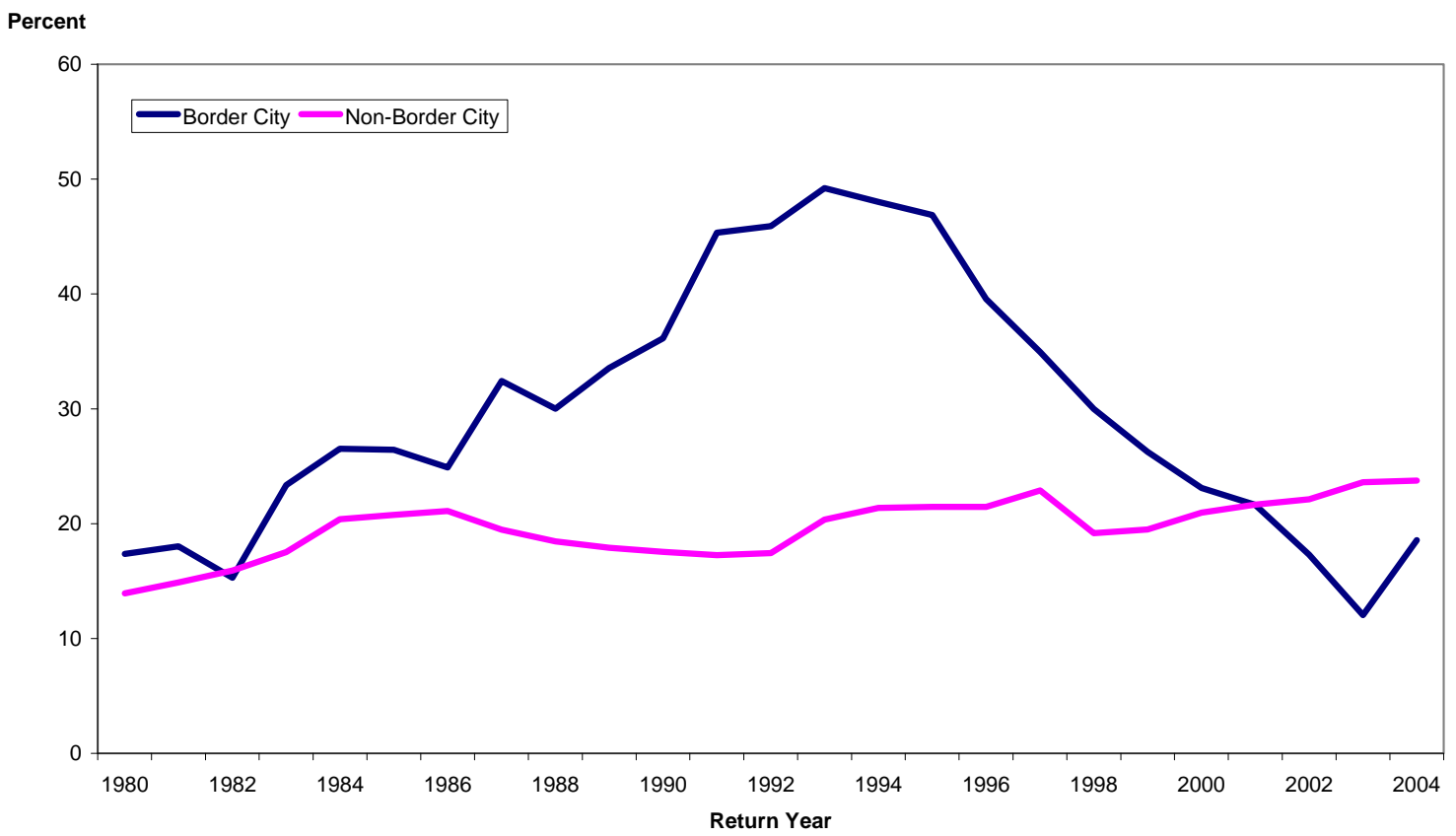

Source: Mexican Migration Project 114

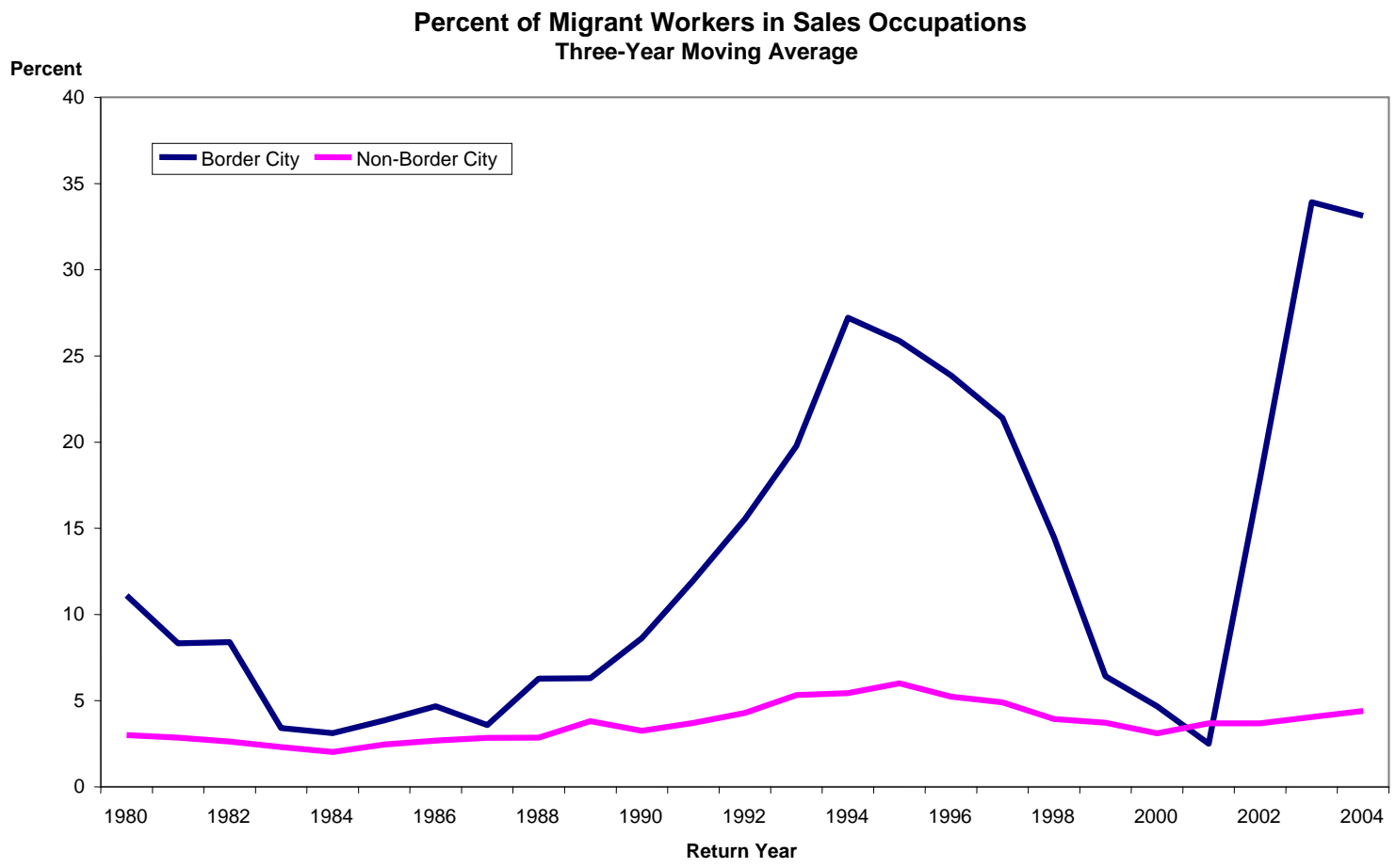

Source: Mexican Migration Project 114 
Figure 7

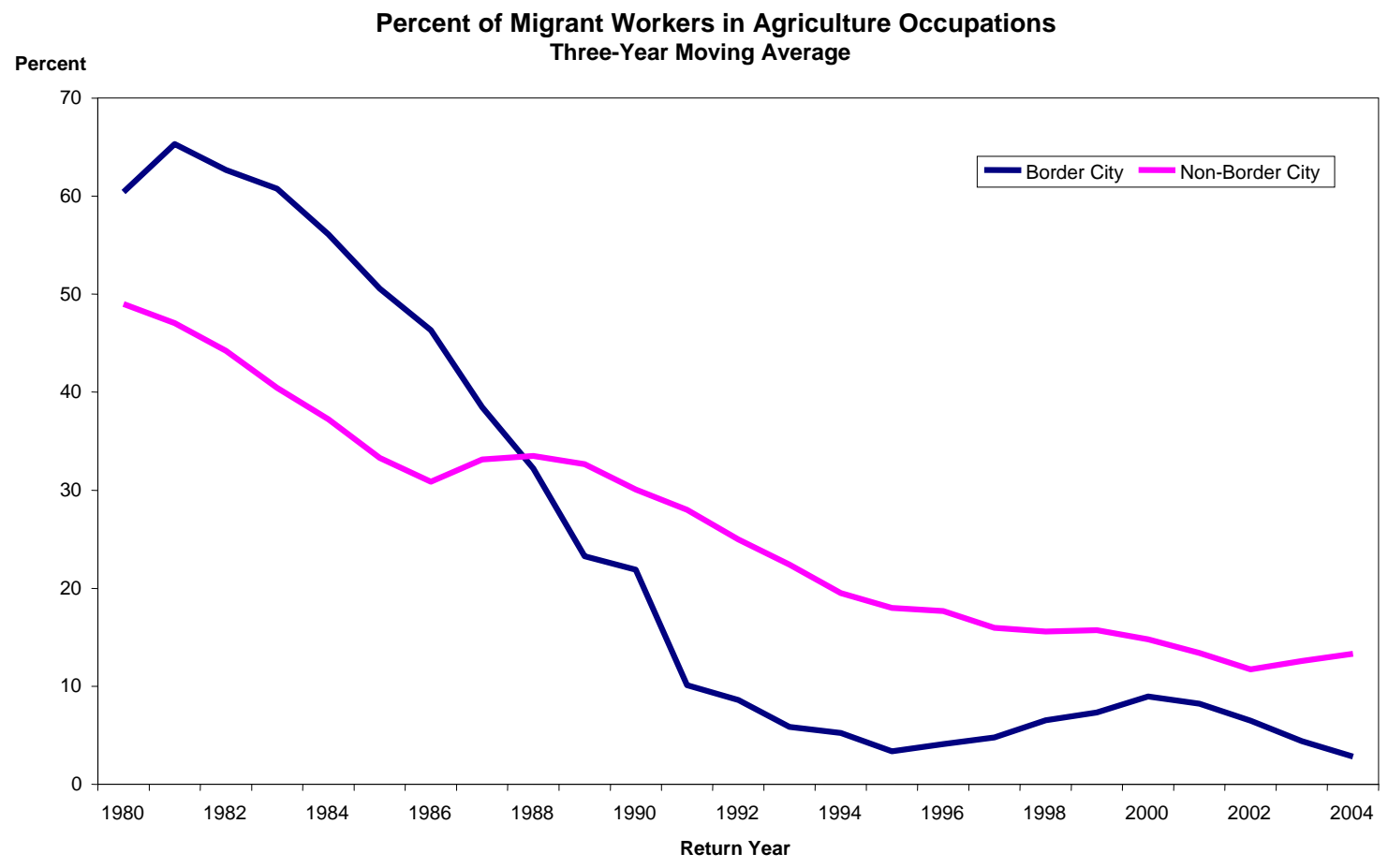

Source: Mexican Migration Project 114 
Table 1

Characteristics of Mexican Migrants

\begin{tabular}{|c|c|c|}
\hline & \multicolumn{2}{|c|}{ Trip Destination } \\
\hline & Border & Non-Border \\
\hline Age & $\begin{array}{c}29.6 \\
(10.7)\end{array}$ & $\begin{array}{l}29.6 \\
(10.5)\end{array}$ \\
\hline Education & $\begin{array}{l}7.08^{* *} \\
(3.53)\end{array}$ & $\begin{array}{c}6.61 \\
(3.56)\end{array}$ \\
\hline Female & $\begin{array}{l}0.21^{* *} \\
(0.41)\end{array}$ & $\begin{array}{c}0.16 \\
(0.36)\end{array}$ \\
\hline Married & $\begin{array}{c}0.76 \\
(0.43)\end{array}$ & $\begin{array}{c}0.75 \\
(0.43)\end{array}$ \\
\hline Family Size & $\begin{array}{l}8.37^{*} \\
(3.81)\end{array}$ & $\begin{array}{l}8.60 \\
(3.78)\end{array}$ \\
\hline Origination & & \\
\hline Central Mexico & $\begin{array}{l}0.05^{* *} \\
(0.23)\end{array}$ & $\begin{array}{c}0.16 \\
(0.36)\end{array}$ \\
\hline Western Mexico & $\begin{array}{l}0.20 * * \\
(0.40)\end{array}$ & $\begin{array}{c}0.52 \\
(0.50)\end{array}$ \\
\hline Northern Mexico & $\begin{array}{l}0.53^{* *} \\
(0.50)\end{array}$ & $\begin{array}{c}0.29 \\
(0.45)\end{array}$ \\
\hline Mexico-US Border & $\begin{array}{l}0.22 * * \\
(0.41)\end{array}$ & $\begin{array}{c}0.04 \\
(0.19)\end{array}$ \\
\hline U.S. Trips & $\begin{array}{l}3.42^{*} \\
(4.00)\end{array}$ & $\begin{array}{l}3.69 \\
(4.68)\end{array}$ \\
\hline No English & $\begin{array}{l}0.29^{*} \\
(0.45)\end{array}$ & $\begin{array}{c}\odot .33 \\
(0.47)\end{array}$ \\
\hline $\begin{array}{l}\text { Illegal crossing } \\
\text { (without documentation) }\end{array}$ & $\begin{array}{l}0.53^{*} * \\
(0.50)\end{array}$ & $\begin{array}{c}0.63 \\
(0.48)\end{array}$ \\
\hline Community Parent Network & $\begin{array}{l}0.18^{* *} \\
(0.38)\end{array}$ & $\begin{array}{c}0.26 \\
(0.44)\end{array}$ \\
\hline Community Sibling Network & $\begin{array}{l}0.39 * * \\
(0.49)\end{array}$ & $\begin{array}{c}0.48 \\
(0.50)\end{array}$ \\
\hline Domestic Migration & $\begin{array}{l}0.25^{* *} \\
(0.43)\end{array}$ & $\begin{array}{c}0.22 \\
(0.41)\end{array}$ \\
\hline On first U.S. Trip & $\begin{array}{l}0.36 \\
(0.48)\end{array}$ & $\begin{array}{l}0.37 \\
(0.48)\end{array}$ \\
\hline Months U.S. Experience & $\begin{array}{l}72.8 \\
(66.9)\end{array}$ & $\begin{array}{l}75.8 \\
(72.4)\end{array}$ \\
\hline Wage (in 2006 US dollars) & $\begin{array}{l}7.47^{*} \\
(4.59)\end{array}$ & $\begin{array}{c}9.08 \\
(5.86)\end{array}$ \\
\hline US Occupation & & \\
\hline Professional & $\begin{array}{l}\odot .04 * * \\
(0.19)\end{array}$ & $\begin{array}{c}0.02 \\
(0.12)\end{array}$ \\
\hline Agriculture & $\begin{array}{l}0.14^{*} \\
(0.35)\end{array}$ & $\begin{array}{c}0.25 \\
(0.43)\end{array}$ \\
\hline Skilled Production & $\begin{array}{l}0.07 * * \\
(0.26)\end{array}$ & $\begin{array}{c}0.15 \\
(0.35)\end{array}$ \\
\hline Unskilled Production & $\begin{array}{l}0.11^{* *} \\
(0.31)\end{array}$ & $\begin{array}{c}0.25 \\
(0.43)\end{array}$ \\
\hline
\end{tabular}




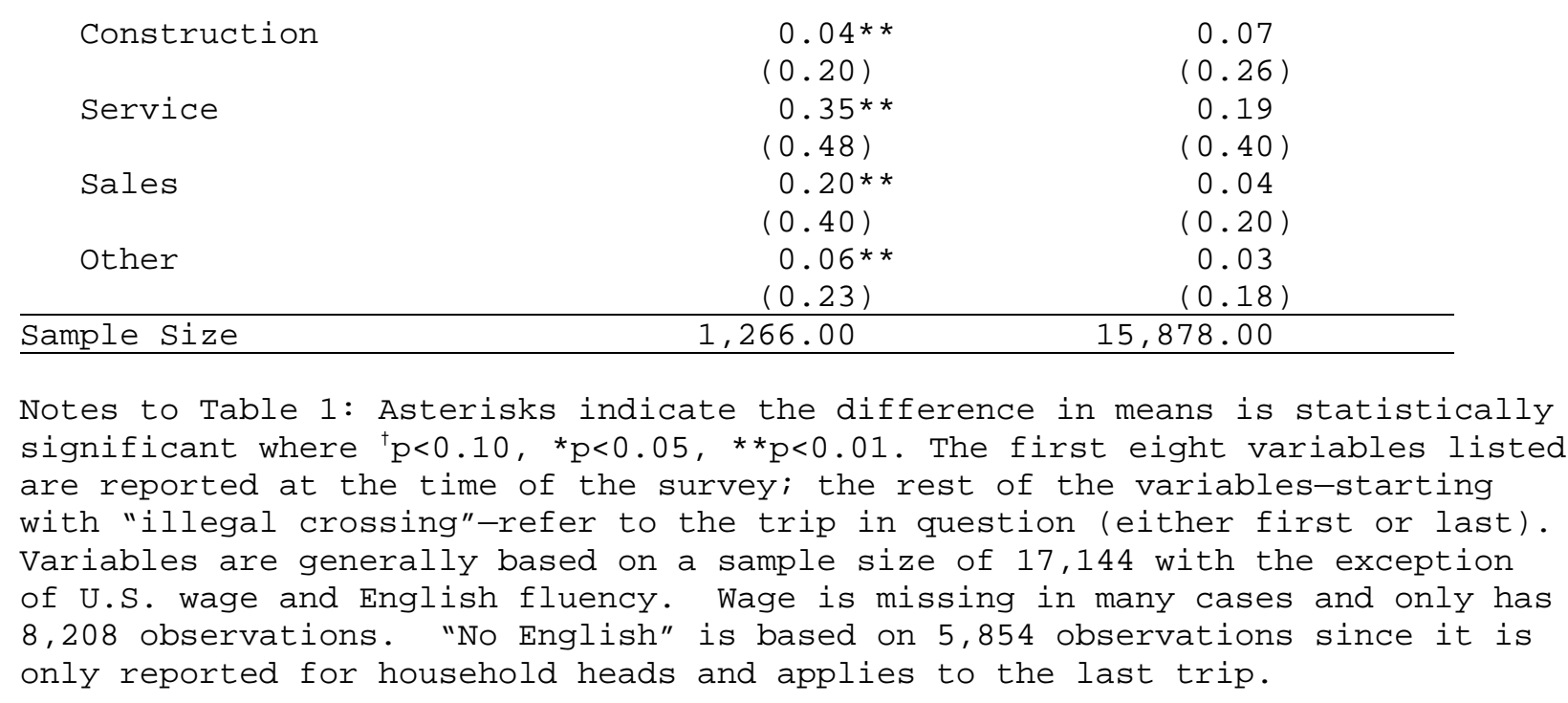

Source: Mexican Migration Project 114 
Table 2

Mexican Migration to the U.S. Border

\begin{tabular}{|c|c|c|c|c|}
\hline & (1) & (2) & (3) & (4) \\
\hline Age & $\begin{array}{l}-0.0003 \\
(0.0004)\end{array}$ & $\begin{array}{l}-0.0005 \\
(0.0004)\end{array}$ & $\begin{array}{l}-0.0005 \\
(\odot .0004)\end{array}$ & $\begin{array}{l}-\odot .00 \odot 4 \\
(\odot .00 \odot 4)\end{array}$ \\
\hline Education & $\begin{array}{c}\odot .0013 \\
(\odot .0009)\end{array}$ & $\begin{array}{c}\odot . \odot \odot \odot \odot \\
(\odot .0 \odot \odot 9)\end{array}$ & $\begin{array}{c}0.0 \odot \odot 2 \\
(\odot .0 \odot \odot 9)\end{array}$ & $\begin{array}{c}\odot .0 \odot \odot 2 \\
(\odot . \odot \odot \odot 9)\end{array}$ \\
\hline Female & $\begin{array}{l}(0.0009) \\
0.0283^{* *} \\
(0.0086)\end{array}$ & $\begin{array}{c}(\odot . \odot \odot \odot 9) \\
\odot . \odot 305^{* *} \\
(\odot .0 \odot 82)\end{array}$ & $\begin{array}{l}\odot .0304^{* *} \\
(0.0081)\end{array}$ & $\begin{array}{c}\odot .0306^{* *} \\
(\odot .0081)\end{array}$ \\
\hline Family Size & $\begin{array}{l}-0.0003 \\
(0.0011)\end{array}$ & $\begin{array}{c}0.0013 \\
(0.0011)\end{array}$ & $\begin{array}{c}0.0011 \\
(\odot .0010)\end{array}$ & $\begin{array}{c}0.0009 \\
(\odot .0010)\end{array}$ \\
\hline Illegal Crossing & $\begin{array}{l}-0.0280^{* *} \\
(0.0081)\end{array}$ & $\begin{array}{l}-\odot .0040 \\
(\odot .0 \odot 76)\end{array}$ & $\begin{array}{l}-0.0045 \\
(\odot .0074)\end{array}$ & $\begin{array}{l}-0.0054 \\
(0.0074)\end{array}$ \\
\hline Community Parent Network & $\begin{array}{l}-0.0559^{* *} \\
(0.0159)\end{array}$ & $\begin{array}{l}-0.0385^{*} \\
(0.0155)\end{array}$ & $\begin{array}{l}-0.0323^{*} \\
(0.0155)\end{array}$ & $\begin{array}{l}-0.0329^{*} \\
(\odot .0155)\end{array}$ \\
\hline Community Sibling Network & $\begin{array}{l}-0.0233^{*} \\
(0.0119)\end{array}$ & $\begin{array}{l}-\odot .0311^{* *} \\
(0.0121)\end{array}$ & $\begin{array}{l}-0.0321^{*} \\
(0.0119)\end{array}$ & $\begin{array}{l}-\odot .0311^{* *} \\
(\odot .0119)\end{array}$ \\
\hline Domestic Migration & $\begin{array}{r}0.0165^{*} \\
(\odot .0077)\end{array}$ & $\begin{array}{r}0.0125^{\dagger} \\
(\odot .0074)\end{array}$ & $\begin{array}{c}0.0133^{\dagger} \\
(0.0074)\end{array}$ & $\begin{array}{c}\odot .0131^{\dagger} \\
(\odot .0074)\end{array}$ \\
\hline First U.S. Trip & $\begin{array}{l}-0.0103 \\
(0.0080)\end{array}$ & $\begin{array}{l}-0.0212^{* *} \\
(\Theta .0072)\end{array}$ & $\begin{array}{l}-0.0189 * * \\
(0.0070)\end{array}$ & $\begin{array}{l}-\odot .0179^{*} \\
(\odot .0 \odot 7 \odot)\end{array}$ \\
\hline Time Trend & & $\begin{array}{c}0.0053^{*} \\
(0.0021)\end{array}$ & $\begin{array}{l}0.0529^{* *} \\
(0.0087)\end{array}$ & $\begin{array}{c}0.0147 \\
(0.0101)\end{array}$ \\
\hline Time Trend Squared & & $\begin{array}{l}-\odot .0002^{* *} \\
(\odot .0001)\end{array}$ & $\begin{array}{l}-0.0002 \\
(0.0002)\end{array}$ & $\begin{array}{l}0.0010^{* *} \\
(0.0003)\end{array}$ \\
\hline Central Mexican state origin & & $\begin{array}{l}-0.0095 \\
(0.0084)\end{array}$ & $\begin{array}{l}-0.0114 \\
(\odot .0089)\end{array}$ & $\begin{array}{l}-\odot .0128 \\
(\odot .0091)\end{array}$ \\
\hline Northern Mexican state origin & & $\begin{array}{l}0.0886^{* *} \\
(0.0100)\end{array}$ & $\begin{array}{l}0.0838^{* *} \\
(0.0092)\end{array}$ & $\begin{array}{l}\odot .0817^{* *} \\
(\odot .009 \odot)\end{array}$ \\
\hline Border Mexican state origin & & $\begin{array}{l}\odot .2877^{*} * \\
(\odot .0245)\end{array}$ & $\begin{array}{l}0.2827^{* *} \\
(\Theta .0244)\end{array}$ & $\begin{array}{l}0.2803^{* *} \\
(0.0244)\end{array}$ \\
\hline Ln Border Employment & & & $\begin{array}{l}-\odot .7596^{* *} \\
(0.2894)\end{array}$ & $\begin{array}{l}-1.0396 \text { ** } \\
(0.2651)\end{array}$ \\
\hline Ln U.S. Employment & & & $\begin{array}{l}-0.0249 \\
(0.4107)\end{array}$ & $\begin{array}{l}1.4722^{* *} \\
(0.4857)\end{array}$ \\
\hline Ln Mexican Real GDP & & & $\begin{array}{l}-1.0693^{* *} \\
(0.1585)\end{array}$ & $\begin{array}{l}-0.4304 \text { * } \\
(0.1533)\end{array}$ \\
\hline Ln Mexican Interest Rate & & & $\begin{array}{l}-0.0110 \\
(0.0076)\end{array}$ & $\begin{array}{l}0.0454 \text { * * } \\
(0.0123)\end{array}$ \\
\hline Ln Visas Issued to Mexicans & & & & $\begin{array}{c}\odot .024 \odot^{\dagger} \\
(\odot .0138)\end{array}$ \\
\hline Ln Linewatch Hours & & & & $\begin{array}{l}-0.2662^{* *} \\
(0.0445)\end{array}$ \\
\hline \multicolumn{5}{|c|}{$\begin{array}{l}\text { Notes to Table 2: Standard errors in parentheses. Coefficients are from LPM } \\
\text { regressions of border versus interior U.S. destination }(\mathrm{N}=16,208) \text { where } \\
\text { border destinations take the value } 1 \text { and interior destinations } \odot \text {. Female, } \\
\text { legal status, domestic migration, first trip, and origin variables are all } \\
\text { dummy variables taking either the value } 1 \text { or } \odot \text {. Economic variables are } \\
\text { expressed in natural logs of their value. Statistical significance is } \\
\text { denoted as follows: }{ }^{\dagger} p<0.10,{ }^{*} p<0.05 ;{ }^{*} p<\odot .01\end{array}$} \\
\hline
\end{tabular}


Table 3

U.S. Wage Outcomes for Mexican Migrants

(1)

Border
Age
Education
Female
Illegal Crossing
Community Parent Network
Community Sibling Network
US Experience
Central Mexican State
Northern Mexican State
Border Mexican State
Education*Border
Illegal*Border

(2)

\begin{tabular}{|c|c|c|}
\hline $\begin{array}{l}-0.1952 * * \\
(0.0976) \\
-0.0028 * * \\
(0.0008) \\
0.0113 * * \\
(0.0025) \\
-0.2581 * * \\
(0.0230) \\
-0.1390 * * \\
(0.0186) \\
0.0513 \\
(0.0423) \\
0.0518 \\
(0.0368) \\
0.0011 * * \\
(0.0001) \\
0.0120\end{array}$ & 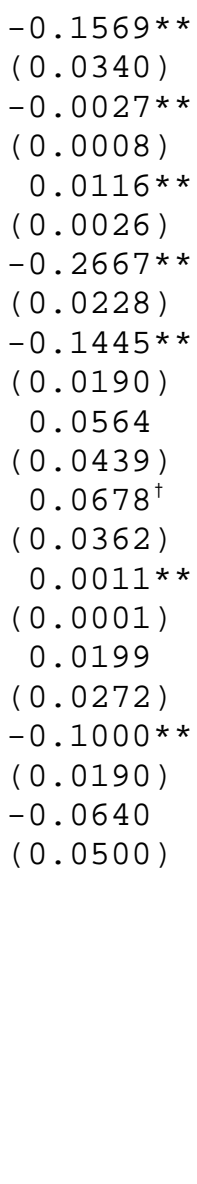 & 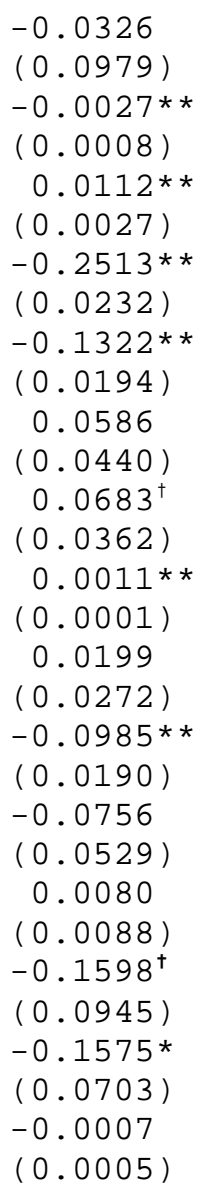 \\
\hline
\end{tabular}

Notes to Table 3: Standard errors in parentheses. Coefficients are from regressions of the natural log of real hourly wage on person and trip characteristics $(\mathrm{N}=7,708)$. Statistical significance is denoted as follows: ${ }^{\dagger} p<0.10,{ }^{*} p<0.05, * * p<0.01$ 


\section{Appendix}

\section{Regression Model Details}

In order to estimate the migration equation, we merge economic and immigration policy data with the MMP data on migration. Annual national and county-level total personal income (deflated using the U.S. CPI-W and expressed in 2006 dollars) are from the Bureau of Economic Analysis Regional Economic Information System (BEA REIS). National as well as county-level employment is based on the Bureau of Labor Statistics (BLS) household survey. We use 91-day yields on Mexican Treasury certificates from Banco de México for the nominal interest rate, which is a proxy for the cost of short-term debt such as credit card rates. Real Mexican GDP (in millions of 1993 pesos) is from Instituto Nacional de Estadística Geografía e Informática (INEGI). We also include the total number of non-immigrant visas issued to Mexicans abroad, to control for border accessibility; the visa data are from the U.S. Department of State Bureau of Consular Affairs. Border enforcement is measured by the annual total of Border Patrol linewatch hours from the Department of Homeland Security. Linewatch hours are a count of the time Border Patrol agents spend patrolling the border to apprehend and deter undocumented migrants (versus the time they spend doing paperwork or other tasks); they are a good measure of enforcement intensity and have been used in a number of studies (see Bean et al. 1990 for papers using enforcement statistics).

To explain border migration in a multivariate setting, we run the following linear probability model of trip $i$ at time $t$ :

$$
\text { Border Destination }_{\mathrm{it}}=\alpha+\beta \mathrm{X}_{\mathrm{it}}+\gamma \mathrm{Z}_{\mathrm{i}}+\sigma \mathrm{Econ}_{\mathrm{t}}+\rho \mathrm{Imm}_{\mathrm{t}}+\tau \mathrm{T}_{\mathrm{t}}+\varepsilon_{\mathrm{it}} \text {, }
$$


where the dependent variable, border destination, takes on the value 1 if the migrant chooses a border destination and 0 otherwise. ${ }^{11}$ The covariates include both time-varying variables, $X_{i t}$, and time-invariant variables, $Z_{i}$. Time-varying controls include a migrant's age in the year of the start of the trip, a dummy variable equal to 1 for an illegal crossing (and 0 for a legal crossing), a dummy variable equal to 1 for it being a migrant's first trip (instead of last, since we examine both first and last trips), and a dummy variable for domestic migration (equal to 1 in cases where the person first migrated within Mexico). Migrant networks are also time-varying and measured by the share of households in the home community that have a household head with a parent or sibling who has migrated to the U.S. previously.

Time-invariant covariates are measured at the time of survey and include the number of years of education, a female dummy variable (equal to 1 if the migrant is female, 0 for males), family size, and dummy variables for 3 of the 4 places of origin (which we classify into west, north, central and border states, as noted above). In addition, certain specifications include the economic control variables described above, including logged values of border employment, U.S. employment, real Mexican GDP and Mexican short-term interest rates. Two controls for immigration policy are also added to certain specifications, the log of the number of temporary visas issued to Mexicans and the log of Border Patrol linewatch hours. Means of the aggregate variables are reported in Table A1. Lastly, a linear time trend and its square are included to control for the common trend in the aggregate variables, such as employment and GDP.

\footnotetext{
${ }^{11}$ Probit regressions yield very similar results so we chose the simpler specification for ease of interpretation.
} 
Table A1

Economic and Immigration Policy Conditions, Annual Means

\author{
Border \\ Border Employment \\ Border Income Per Capita \\ (2006 dollars) \\ $2,013,641.00$ \\ $(310,238.10)$ \\ $25,641.58$ \\ $(1,965.77)$ \\ U.S. \\ U.S. Employment \\ $118,357,633.92$ \\ U.S. Income Per Capita \\ $(10,327,877.07)$ \\ $29,537.51$ \\ (2006 dollars) \\ $(2,671.62)$ \\ Mexico \\ Real Mexican GDP \\ (millions 1993 pesos) \\ Mexican Short-Term Interest Rate \\ (nominal) \\ $1,196,225.00$ \\ $(185,404.80)$ \\ 39.35 \\ $(24.32)$ \\ Immigration Policy \\ Border Patrol Linewatch Hours \\ $3,441,048.00$ \\ $(2,157,916.00)$ \\ $57,044.04$ \\ Visas Issued to Mexicans \\ $(17,651.30)$ \\ Sample Size \\ $17,051.00$ \\ Notes to Table A1: Sample period 1980-2004, border city totals reflect sum \\ across all cities. Standard deviations are in parentheses. \\ Source: See text.
}

